\title{
Pemanfaatan Pelayanan Voluntary Counselling and Testing (VCT) HIV Pada Ibu Hamil di Wilayah Kerja Puskesmas Langsat Pekanbaru Tahun 2018
}

\author{
Ifni Wilda \\ Program Studi Magister Ilmu Kesehatan Masyarakat STIKes Hang Tuah Pekanbaru \\ Email : ifniwilda1@gmail.com
}

\begin{abstract}
ABSTRAK
Selama lebih dari 20 tahun layanan VCT disediakan, cakupan global dari ODHA yang menggunakan pelayanan VCT masih rendah. UNAIDS melaporkan bahwa 80\% ODHA di dunia tidak mengetahui bahwa mereka terinfeksi HIV karena mereka belum menggunakan layanan VCT untuk memeriksakan status kesehatannya terkait HIV. VCT adalah konseling dan tes HIV sukarela yang merupakan pintu masuk untuk membantu setiap orang mendapatkan akses ke semua pelayanan HIV. Puskesmas Langsat merupakan puskesmas dengan persentase ibu hamil yang memanfaatkan Pelayanan VCT terendah yaitu 21,6\%. Tujuan Penelitian ini untuk mengetahui faktor yang berhubungan dengan Pemanfaatan Pelayanan Voluntary Counselling And Testing (VCT) HIV Pada Ibu Hamil Di Wilayah Kerja Puskesmas Langsat Pekanbaru Tahun 2018. Metode Penelitian bersifat kuantitatif analitik observasional dengan studi crosssectional. Populasi Penelitian berjumlah 571 ibu hamil dengan sampel $180 \mathrm{ibu}$. Analisis data dilakukan secara univariat, bivariat dengan uji chi square, dan multivariat dengan uji regresi logistik ganda. Berdasarkan hasil analisis multivariat, variabel yang paling berhubungan dengan Pemanfaatan Pelayanan VCT pada ibu hamil di Wilayah Kerja Puskesmas Langsat Tahun 2018 adalah variabel Dukungan Suami/Keluarga (POR:2,002) dan dukungan Tenaga Kesehatan (POR:2,571). Kesimpulan ibu yang mendapatkan dukungan suami/keluarga 2 kali memanfaatkan pelayanan VCT, ibu yang mendapatkan dukungan tenaga kesehatan 2,5 kali memanfaatkan pelayanan VCT. Diharapkan kepada tenaga kesehatan untuk meningkatkan sosialisasi tentang program VCT, khususnya kepada ibu hamil yang berisiko,suami/kelaurga melalui media massa, cetak dan elektronik dan meningkatkan screening dengan melakukan VCT untuk semua ibu hamil yang datang ANC ke fasilitas kesehatan.
\end{abstract}

Kata Kunci: Pemanfaatan Pelayanan VCT, Dukungan Suami/Keluarga, Dukungan Tenaga Kesehatan, Puskesmas Langsat Pekanbaru

\section{ABSTRACT}

For more than 20 years VCT services have been provided, global coverage of PLWHA who use VCT services is still low. UNAIDS reports that $80 \%$ of people living with HIV in the world do not know that they are infected with HIV because they have not used VCT services to check their health status related to HIV. VCT is voluntary HIV testing and counseling which is the entry point to help everyone get access to all HIV services. Langsat Health Center is a health center with the percentage of pregnant women utilizing the lowest VCT service, which is 21.6\%. The purpose of this study was to determine the factors related to the use of HIV Voluntary Counseling and Testing Services in Pregnant Women in the Work Area of Langsat Pekanbaru Public Health Center in 2018. The research method was quantitative observational analytic with cross sectional studies. Study population numbered 571 pregnant women with a sample of 180 mothers. Data analysis was carried out by univariate, bivariate with chi square test, and multivariate by multiple logistic regression test. Based on the results of multivariate analysis, the variables most related to VCT Service Utilization in pregnant women in the Langsat Health Center Work Area in 2018 are variables of Husband / Family Support (POR: 2,002) and support from Health Workers (POR: 2,571). Conclusion The mother who received husband / family support 2 times using VCT services, the mother who received the support of health workers 2.5 times made use of VCT services. Expected to health workers to increase the socialization of VCT programs, especially to pregnant women who are at risk, husbands / families through mass media, print and electronic and improve screening by conducting VCT for all pregnant women who come to ANC to health facilities.

Key word: Utilization of VCT Services, Husband / Family Support, Support of Health Workers, Langsat Pekanbaru Health Center

\section{PENDAHULUAN}

Perempuan yang terinfeksi HIV setiap tahun mengalami peningkatan dengan kasus tertinggi sebanyak 12.302 pada Ibu Rumah Tangga, seiring dengan terjadinya peningkatan jumlah laki - laki yang melakukan hubungan seksual yang tidak aman, yang akan menularkan HIV pada pasangan seksualnya (Kemenkes RI, 2017). 
Ketika terjadinya kehamilan, Virus HIV bukan hanya ancaman pada keselamatan jiwa ibu, tetapi juga ancaman bagi bayi yang dikandungnya. Tanpa upaya khusus, Estimasi dan proyeksi ibu hamil positif HIV mengalami peningkatan, dari tahun 2011 sebesar 14.194 menjadi 19.636 di tahun 2016 (Kementerian Kesehatan, 2014). Dan diperoleh Kasus lebih dari 90\% Anak dengan HIV yang mendapatkan infeksi dengan cara penularan dari ibunya (Kementerian Kesehatan, 2013).

Salah satu program Penanggulangan HIV/AIDS yang ditetapkan oleh United Nations Programme on HIV and AIDS (UNAIDS) adalah program Harm Reduction (UNAIDS, 2017). Salah satu program dari pengurangan dampak buruk (Harm Reduction) adalah program VCT (Yulianti, 2011). Identifikasi ibu hamil yang terinfeksi HIV melalui Voluntary Counselling and Testing (VCT) merupakan langkah awal dalam penetapan intervensi. Panduan untuk mengajak ibu hamil melakukan konseling dan tes, pertama kali dikeluarkan pada tahun 1995 oleh layanan kesehatan masyarakat USA (Agnes et al., 2010)

Berdasarkan Kebijakan Menteri Kesehatan Republik Indonesia Nomor 21 Tahun 2003 Tentang Penanggulangan HIV AIDS, dalam pasal 17 disebutkan bahwa semua ibu hamil yang melakukan pemeriksaan kehamilannya diharuskan mengikuti pemeriksaan HIV dengan Tes dan Konseling (VCT) sebagai upaya pencegahan ibu ke anak yang dikandungnya.(Kementerian Kesehatan, 2013).

Berdasarkan data dari Dinas Kesehatan Kota Pekanbaru Tahun 2016 menunjukkan dari 20 Puskesmas yang ada di Kota Pekanbaru, persentase ibu hamil yang memanfaatkan Pelayanan VCT terendah berada di Puskesmas Langsat yaitu sebesar 21,6\% tahun 2017 dan 8,37\% tahun 2016.

\section{METODE}

Jenis penelitian yang digunakan dalam penelitian ini adalah analitik kuantitatif dengan desain Crosssectional Study. Sampel dalam penelitian ini adalah seluruh ibu hamil yang ada di Wilayah Kerja Puskesmas Langsat Pekanbaru yang berjumlah 180 orang. Pengambilan sampel mengacu pada data ibu hamil yang ada disetiap kelurahan yang telah dikumpulkan di bagian KIA Puskesmas Langsat kota Pekanbaru, pengumpulan data dilakukan di wilayah kerja puskesmas. Jenis data yang dikumpulkan adalah data primer. Data primer diperoleh dari pengisian kuesioner untuk variabel independen yaitu pengetahuan, Persepsi, Stigma dan Diskriminasi, dukungan suami/keluarga, dukungan tenaga kesehatan, ketersediaan informasi, pendidikan, umur.

Pengolahan data dilakukan dalam tahap-tahap editing, coding, processing, cleaning dan tabulating. Analisis data dilakukan secara univariat, bivariat dengan uji chi square dan analisis multivariat dengan multiple logistic regression.

\section{HASIL}

\section{Analisis Univariat}

Pada analisa univariat didapatkan hasil dari 180 responden yang diteliti terdapat sebanyak 68,9 persen persepsi rendah, sebanyak 55,6 persen menyatakan tidak tersedia informasi, sebanyak 25 persen ibu berpendidikan rendah, sebanyak 57,8 persen ibu berada pada umur beresiko. Sebanyak 50,6 persen ibu dengan stigma dan diskriminasi rendah, sebanyak 55,6 ibu tidak mendapatkan dukungan suami, sebanyak 60 persen ibu dengan pengetahuan kurang baik dan 97 persen ibu tidak mendapatkan dukungan dari tenaga kesehatan. 
Tabel 1

Distribusi Frekuensi Variabel Independen Pemanfaatan Pelayanan Voluntary Counselling and Testing (VCT) pada Ibu Hamil di Wilayah Kerja Puskesmas Langsat Pekanbaru Tahun 2018

\begin{tabular}{|c|c|c|}
\hline \multirow{2}{*}{ Variabel Independen } & \multicolumn{2}{|c|}{ Jumlah } \\
\hline & (n) & $(\%)$ \\
\hline \multicolumn{3}{|l|}{ Persepsi } \\
\hline Rendah & 124 & 68,9 \\
\hline Tinggi & 56 & 31,1 \\
\hline \multicolumn{3}{|l|}{ Ketersediaan Informasi } \\
\hline Tidak tersedia & 100 & 55,6 \\
\hline Tersedia & 80 & 44,4 \\
\hline \multicolumn{3}{|l|}{ Pendidikan } \\
\hline Rendah & 45 & 25,0 \\
\hline Tinggi & 135 & 75,0 \\
\hline \multicolumn{3}{|l|}{ Umur } \\
\hline Beresiko & 104 & 57,8 \\
\hline Tidak beresiko & 76 & 42,2 \\
\hline \multicolumn{3}{|l|}{ Stigma dan Diskriminasi } \\
\hline Rendah & 91 & 50,6 \\
\hline Tinggi & 89 & 49,4 \\
\hline \multicolumn{3}{|l|}{ Dukungan suami/keluarga } \\
\hline Tidak mendukung & 100 & 55,6 \\
\hline Mendukung & 80 & 44,4 \\
\hline \multicolumn{3}{|l|}{ Pengetahuan } \\
\hline Kurang baik & 108 & 60,0 \\
\hline Baik & 72 & 40,0 \\
\hline \multicolumn{3}{|l|}{ Dukungan Tenaga Kesehatan } \\
\hline Tidak Mendukung & 97 & 53,9 \\
\hline Mendukung & 83 & 46,1 \\
\hline
\end{tabular}

\section{Analisis Bivariat}

Dari analisis bivariat didapatkan hasil dari 8 variabel independen ada enam variabel yang berhubungan signifikan $(\mathrm{p}<0,05)$ dengan pemanfaatan pelayanan VCT oleh ibu hamil, yaitu variabel Persepsi, Ketersediaan informasi, stigma dan diskriminasi, dukungan suami/keluarga, pengetahuan dan dukungan tenaga Kesehatan. Sedangkan variabel yang tidak berhubungan $(p>0,05)$ yaitu Pendidikan ibu dan umur ibu.

Tabel 2

Hubungan Variabel Independen Terhadap Pemanfaatan Pelayanan Voluntary Counselling and Testing (VCT) pada Ibu Hamil di Wilayah Kerja Puskesmas Langsat Pekanbaru Tahun 2018

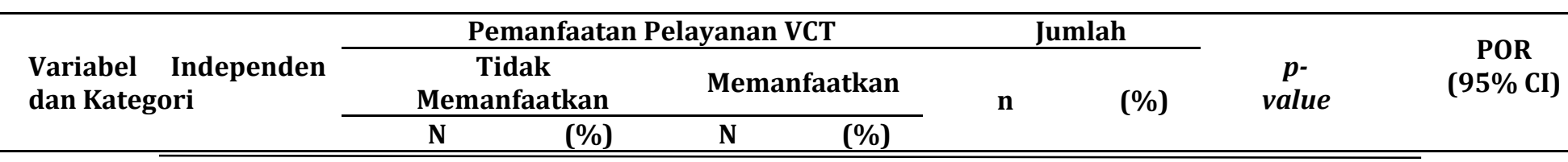




\begin{tabular}{|c|c|c|c|c|c|c|c|c|}
\hline $\begin{array}{l}\text { Persepsi } \\
\text { Rendah } \\
\text { Tinggi } \\
\end{array}$ & $\begin{array}{l}57 \\
47 \\
\end{array}$ & $\begin{array}{l}46,0 \\
83,9 \\
\end{array}$ & $\begin{array}{c}67 \\
9 \\
\end{array}$ & $\begin{array}{l}54,0 \\
16,1 \\
\end{array}$ & $\begin{array}{c}124 \\
56 \\
\end{array}$ & $\begin{array}{l}100,0 \\
100,0 \\
\end{array}$ & 0,000 & $\begin{array}{c}0,163 \\
(0,074-0,361)\end{array}$ \\
\hline $\begin{array}{l}\text { Ketersediaan informasi } \\
\text { Tidak tersedia } \\
\text { Tersedia }\end{array}$ & $\begin{array}{l}48 \\
56 \\
\end{array}$ & $\begin{array}{l}48,0 \\
70,0\end{array}$ & $\begin{array}{l}52 \\
24\end{array}$ & $\begin{array}{l}52,0 \\
30,0\end{array}$ & $\begin{array}{c}100 \\
80\end{array}$ & $\begin{array}{l}100,0 \\
100,0\end{array}$ & 0,005 & $\begin{array}{c}0,396 \\
(0,213-0,734)\end{array}$ \\
\hline $\begin{array}{l}\text { Pendidikan } \\
\text { Rendah } \\
\text { Tinggi } \\
\end{array}$ & $\begin{array}{l}23 \\
81 \\
\end{array}$ & $\begin{array}{l}51,1 \\
60,0 \\
\end{array}$ & $\begin{array}{l}22 \\
54 \\
\end{array}$ & $\begin{array}{l}48,9 \\
40,0 \\
\end{array}$ & $\begin{array}{c}45 \\
135 \\
\end{array}$ & $\begin{array}{l}100,0 \\
100,0\end{array}$ & 0,384 & $\begin{array}{c}0,697 \\
(0,354-1,374)\end{array}$ \\
\hline $\begin{array}{l}\text { Umur } \\
\text { Berisiko } \\
\text { Tidak berisiko } \\
\end{array}$ & $\begin{array}{l}56 \\
48 \\
\end{array}$ & $\begin{array}{l}53,8 \\
63,2 \\
\end{array}$ & $\begin{array}{l}48 \\
28 \\
\end{array}$ & $\begin{array}{l}46,2 \\
36,8 \\
\end{array}$ & $\begin{array}{c}104 \\
76 \\
\end{array}$ & $\begin{array}{l}100,0 \\
100,0 \\
\end{array}$ & 0,273 & $\begin{array}{c}0,681 \\
(0,372-1,246)\end{array}$ \\
\hline $\begin{array}{l}\text { Stigma/Diskriminasi } \\
\text { Rendah } \\
\text { Tinggi }\end{array}$ & $\begin{array}{l}43 \\
61 \\
\end{array}$ & $\begin{array}{l}47,3 \\
68,5 \\
\end{array}$ & $\begin{array}{l}48 \\
28 \\
\end{array}$ & $\begin{array}{l}52,7 \\
31,5 \\
\end{array}$ & $\begin{array}{l}91 \\
89 \\
\end{array}$ & $\begin{array}{l}100,0 \\
100,0\end{array}$ & 0,006 & $\begin{array}{c}0,411 \\
(0,224-0,775)\end{array}$ \\
\hline $\begin{array}{l}\text { Dukungan } \\
\text { Suami/Keluarga } \\
\text { Tidak mendukung } \\
\text { Mendukung } \\
\end{array}$ & $\begin{array}{l}65 \\
39 \\
\end{array}$ & $\begin{array}{l}65,0 \\
48,8 \\
\end{array}$ & $\begin{array}{l}35 \\
41 \\
\end{array}$ & $\begin{array}{l}35,0 \\
51,3 \\
\end{array}$ & $\begin{array}{c}100 \\
80 \\
\end{array}$ & $\begin{array}{l}100,0 \\
100,0\end{array}$ & 0,041 & $\begin{array}{c}1,952 \\
(1,071-3,561)\end{array}$ \\
\hline $\begin{array}{l}\text { Pengetahuan } \\
\text { Kurang baik } \\
\text { Baik }\end{array}$ & 52 & 72, & $\begin{array}{l}56 \\
20\end{array}$ & $\begin{array}{l}51,9 \\
27,8\end{array}$ & $\begin{array}{l}108 \\
72\end{array}$ & $\begin{array}{l}100,0 \\
100,0\end{array}$ & 0,002 & $\begin{array}{c}0,357 \\
(0,188-0,677)\end{array}$ \\
\hline $\begin{array}{l}\text { Dukungan Nakes } \\
\text { Tidak Mendukung } \\
\text { Mendukung }\end{array}$ & $\begin{array}{l}65 \\
39\end{array}$ & $\begin{array}{l}61,0 \\
47,0\end{array}$ & $\begin{array}{l}32 \\
44\end{array}$ & $\begin{array}{l}33,0 \\
53,0\end{array}$ & $\begin{array}{l}97 \\
83\end{array}$ & $\begin{array}{l}100,0 \\
100,0\end{array}$ & 0,010 & $\begin{array}{c}2,292 \\
(1,253-4.193)\end{array}$ \\
\hline
\end{tabular}

Analisis Multivariat

Tabel 3

Pemodelan Multivariat Akhir

\begin{tabular}{|c|c|c|c|c|c|c|}
\hline \multirow[t]{2}{*}{ No } & & \multirow{2}{*}{ Variabel } & \multirow{2}{*}{$p$-value } & \multirow{2}{*}{ POR } & \multicolumn{2}{|c|}{ (95\% CI) } \\
\hline & & & & & Lower & Upper \\
\hline 1. & Persepsi & 7 & 0,000 & 0,162 & 0,059 & 0,445 \\
\hline 2. & Stigma de & n Diskriminasi & 0,011 & 0,401 & 0,199 & 0,811 \\
\hline 3. & Dukunga & Suami & 0,052 & 2,002 & 0,994 & 4,033 \\
\hline 4. & Pengetah & & 0,024 & 0,433 & 0,209 & 0,898 \\
\hline 5. & $\begin{array}{l}\text { Dukungal } \\
\text { Ketersedi }\end{array}$ & $\begin{array}{l}\text { Tenaga Kesehatan } \\
\text { aan Informasi }\end{array}$ & 0,008 & 2,571 & 1,274 & 5,185 \\
\hline $\begin{array}{l}6 . \\
7 .\end{array}$ & Umur & & $\begin{array}{l}0,210 \\
0,080\end{array}$ & $\begin{array}{l}0.632 \\
2,128\end{array}$ & $\begin{array}{l}0,308 \\
0,913\end{array}$ & $\begin{array}{l}1,295 \\
4,959\end{array}$ \\
\hline
\end{tabular}

Untuk analisis multivariat dilakukan beberapa tahapan yang pertama yaitu seleksi bivariat untuk mengetahui variabel mana yang akan dimasukkan ke dalam permodelan multivariat. Selanjutnya pemeriksaan counfounding (perubahan OR $>10 \%$ ) dengan mengeluarkan variabel yang $p$ valuenya $\geq 0,05$ secara bertahap dari $p$ value yang besar. Pada penelitian ini didapatkan hasil permodelan akhir variabel yang berhubungan signifikan terhadap pemanfaatan pelayanan VCT yaitu Dukungan suami/keluarga, dan dukungan tenaga kesehatan

\section{PEMBAHASAN}

\section{a. Dukungan Suami/Keluarga}

Pada penelitian ini ditemukan bahwa ibu hamil yang mendapatkan dukungan suami/keluarga 2 kali untuk memanfaatkan pelayanan VCT dibandingkan ibu hamil yang tidak mendapatkan dukungan suami/keluarga. 
Hal ini sejalan dengan penelitan (Nurhayati, 2016) yang menunjukkan ada hubungan yang bermakna antara dukungan suami/keluarga dengan keikutsertaan ibu hamil dalam pemeriksaan VCT di Puskesmas Guguk Panjang Kota Bukittinggi tahun 2016 dengan nilai $p$ value = 0,016 dan OR=6,611). Penelitian (Legiati, Shaluhiyah, \& Suryoputro, 2010) tentang prilaku ibu hamil untuk tes HIV di Kelurahan Bandarharjo dan Tanjung Mas Kota Semarang, dimana OR untuk variabel dukungan suami adalah 15,7111 yang artinya ibu yang mendapatkan dukungan suami 15,711 kali lebih memungkinkan untuk mengikuti tes HIV dibandingkan dengan ibu yang tidak mendapatkan dukungan suami.

Suami dan keluarga merupakan unit terkecil dalam tatanan masyarakat sekaligus menjadi bagian yang paling dekat dan berpengaruh terhadap seseorang. Keluarga memberikan dukungan berupa dukungan informasi maupun instrumental yang berpengaruh terhadap keputusan seseorang dalam pemanfaatan pelayanan kesehatan.

Dorongan dan dukungan suami/keluarga sangat membantu dalam pembentukan prilaku kesehatan ibu hamil karena ibu akan cenderung menuruti apa yang disarankan oleh suami atau keluarganya. seperti yang dinyatakan L.Green bahwa faktor penguat adalah faktor-faktor yang akan datang dari perilaku yang memberikan penghargaan (reward) atau perangsang untuk perilaku tersebut dan menyumbang kelangsungan dan pengulangan perilaku tersebut, diantaranya adalah dukungan suami (Green, 1991). Dukungan suami sangat penting dalam hal ini karena masih adanya budaya patriarki, dimana suami merupakan kepala keluarga dan pengambil keputusan dalam keluarga. Partisipasi suami akan mendukung ibu hamil untuk datang ke pelayanan kesehatan ibu dan anak, serta membantu ibu hamil pada saat-saat penting, seperti menentukan apakah ingin melakukan konseling sukarela (VCT) hingga menjalani tes HIV, mengambil hasil tes, menggunakan obat ARV ataupun memilih makanan bayi agar tidak tertular HIV.

Dari hasil penelitian dilapangan, ditemukan masih banyak suami yang tidak memberikan dukungan kepada istrinya untuk memanfaatkan pelayan VCT karena alasan suami sibuk bekerja dan tidak bisa mendampingi ibu untuk memeriksakan kehamilannya.

\section{b. Dukungan Tenaga Kesehatan}

Pada penelitian ini ditemukan bahwa ibu hamil yang mendapatkan dukungan tenaga kesehatan 2,5 kali untuk memanfaatkan pelayanan VCT dibandingkan ibu hamil yang tidak mendapatkan dukungan tenaga kesehatan. Penelitian (Nurhayati, 2016) didapatkan hasil yang signifikan antara peran tenaga kesehatan dengan keikutsertaan ibu hamil dalam pemeriksaan VCT dengan nilai $P$ Value $=0,000$ dan $\mathrm{OR}=69$ yang artinya ibu hamil yang mendapatka dukungan dari tenaga kesehatan 69 kali ikut serta dalam pemeriksaan VCT dibandingkan ibu yang tidak mendapatkan dukungan tenaga kesehatan.

Dalam penelitian (Indriyani, 2012) dimana hasil uji statistic tentang dukungan tenaga kesehatan dengan partisipasi untuk VCT adalah $p$ value $=0,047$ nilai odd Ratio ( OR 2,533) yang berarti bahwa responden yang mendapatkan dukungan dari tenaga kesehatan mempunyai peluang 2 kali untuk berpartisipasi dalam VCT dibandingkan dengan yang tidak mendapatkan dukungan dari tenaga kesehatan. Dalam penelitian (Ananda, Kamil, \& Rismayanti, 2012) didapatkan hasil yang signifikan 
antara hubungan dukungan tenaga kesehatan dengan pemanfaatan pelayanan VCT dengan nilai $p$ Value $=0,002$.

Hal ini sejalan dengan penelitian (Legiati, Shaluhiyah, \& Suryoputro, 2010) tentang prilaku ibu hamil untuk tes HIV di Kelurahan Bandarharjo dan Tanjung Mas Kota Semarang, dimana hubungan dukungan bidan dengan prilku tes didapatkan $p$ value=0,000.

Petugas kesehatan mempunyai peran majemuk dan menentukan dalam program penanggulangan HIV/AIDS yang meliputi pemberian informasi dasar tentang penularan dan penyebaran HIV serta cara pencegahannya, pemeriksaan deteksi dini, motivasi pasien untuk pemeriksaan HIV sukarela dan melakukan konseling yang tepat. (Ananda et al., 2012). Meski seseorang memiliki pengetahuan yang baik tentang prilaku sehat, belum tentu dia akan mempraktikkan prilaku tersebut. Karena itu diperlukan adanya dorongan dari luar individu tersebut untuk mempraktekkan prilaku sehat sesuai yang diketahui dan diyakininya. Peran tenaga kesehatan masih menjadi faktor dorongan utama yang mempengaruhi pemanfaatan VCT.

Menurut analisis peneliti banyak nya ibu hamil yang kurang mendapatkan dukungan dari tenaga kesehatan dikarenakan petugas kesehatan jarang melakukan penyuluhan kepada ibu hamil tentang pelayanan VCT dan/mungkin kurangnya jumlah petugas laboratorium yang melakukan pemeriksaan VCT kepada ibu hamil yang berkunjung, serta petugas kesehatan tidak pernah memberikan brosur kepada ibu hamil yang berkaitan dengan pentingnya melakukan pemeriksaan VCT.

Disamping itu banyaknya ibu hamil yang tidak mendapatkan dukungan dari tenaga kesehatan untuk memanfaatkan VCT dikarenakan belum optimalnya pelaksanaan standar pelayanan antenatal terpadu oleh tenaga kesehatan yang didalamnya terdapat pelayanan HIV/AIDS untuk ibu hamil meskipun kebijakan Menteri Kesehatan RI No 21 Tahun 2013 telah disebutkan bahwa semua ibu hamil yang melakukan pemeriksaan kehamilan diharuskan mengikuti pemeriksaan HIV dengan Tes dan Konseling (VCT). Hal ini mungkin disebabkan karena belum terakomodasinya kebijakan, strategi, kegiatan dari program terkait

\section{c. Persepsi}

Penelitian ini menunjukkan bahwa ada hubungan protektif antara variabel persepsi dengan pemanfaatan pelayanan VCT. Hasil analisa statistik menunjukkan bahwa ibu hamil yang memiliki persepsi yang tinggi 0,162 kali lebih memanfaatkan pelayanan VCT dibandingkan dengan ibu hamil yang memiliki persepsi yang rendah dengan Confidence Interval (CI) 0,059-0,445. Untuk hasil nilai POR yang bersifat protektif (karena nilainya <1), bisa dibalik dengan menjadikan nilai tersebut 1/POR. Maka menjadi 1/0,162 dan bila dihitung 1 dibagi 0,162 menjadi 6,17. Dapat diinterpretasikan bahwa ibu hamil yang memiliki persepsi yang rendah 6,17 kali lebih besar untuk memanfaatkan pelayanan VCT dibandingkan ibu hamil yang memiliki persepsi yang tinggi. Hubungan protektif ini mungkin disebabkan karena variabel persepsi memiliki 2 variabel Confounding yaitu variabel ketersediaan informasi dan umur. Hal ini kemungkinan terjadi karena ketersediaan informasi dan umur mempengaruhi persepsi ibu.

Persepsi merupakan pengalaman terhadap suatu objek, peristiwa, atau hubungan - hubungan yang diperoleh dengan menyimpulkan informasi dan menafsirkannya (Notoatmodjo, 2010). 
Persepsi yang tinggi tentang Pelayanan VCT tidak serta merta meningkatkan pemanfaatan Pelayanan VCT. Hal tersebut dikarenakan ada faktor harapan yang bersama-sama dengan faktor persepsi mempengaruhi tingkat kepuasan seseorang terhadap suatu pelayanan, dalam hal ini pelayanan dari Pelayanan VCT. Sikap yang baik dari petugas kesehatan terhadap Pelayanan VCT tidak selamanya mampu meningkatkan jumlah kunjungan klien ke Pelayanan VCT. Hal ini disebabkan adanya pertimbangan untung dan rugi dari suatu perilaku.

Menurut (Glanz, Barbara, \& Viswanath, 2008) dalam teori Health Belief Model dinyatakan bahwa pengetahuan membentuk beberapa persepsi dalam proses pencegahan terhadap suatu penyakit. Persepsi membentuk stigma terhadap sesuatu. keikutsertaan dalam tes HIV juga dipengaruhi oleh faktor yang lain misalnya pendidikan dan pengetahuan tentang berbagai aspek HIV/AIDS merupakan faktor yang ditemukan oleh peneliti bisa memainkan peran dalam keputusan untuk memanfaatkan Pelayanan VCT.

Adanya persepsi tidak memiliki resiko untuk terjangkiti HIV/AIDS dapat menjadi salah satu penghambat dalam pemanfaatan VCT. Anggapan ini mungkin disebabkan karena mayoritas responden memiliki pengetahuan yang kurang. Klinik layanan VCT bersifat sukarela atas keinginan klien akan sangat berkaitan dengan faktor kebutuhan klien untuk memanfaatkan layanan klinik VCT. Mungkin kebutuhan klien terhadap pelayanan VCT cukup tinggi walaupun mereka memiliki persepsi yang rendah. Dalam teori Health Belief Model dijelaskan bahwa dalam melakukan tindakan dalam mencegah terjadinya suatu penyakit maupun mencari pengobatan dipe-ngaruhi oleh perceived severity yaitu persepsi keparahan yang mungkin dirasakan bila menderita suatu penyakit. Persepsi ini merupakan pandangan individu tentang beratnya penyakit yang diderita. Pandangan ini mendorong seseorang untuk mencari pengobatan atas penyakit yang dideritanya. Keseriusan ini ditambah dengan akibat dari suatu penyakit misalnya kematian, pengurangan fungsi fisik dan mental, kecacatan dan dampaknya terhadap kehidupan sosial. Hal ini sejalan dengan penelitian (Fibriana, 2013) yang menunjukkan ada hubungan yang signifikan antara persepsi keparahan dengan praktik VCT dengan nilai $P$ Value 0,004 dan nilai $\mathrm{OR}=8$ yang berarti ibu yang memiliki persepsi keparahan yang mungkin dirasakan bila menderita suatu penyakit 8 kali lebih cenderung untuk memanfaatkan praktik layanan VCT.

\section{d. Stigma dan Diskriminasi}

Penelitian ini menunjukkan bahwa ada hubungan protektif antara variabel Stigma dan Diskriminasi dengan pemanfaatan pelayanan VCT.

Hubungan protektif ini dapat terjadi karena Bias informasi, walaupun telah dilakukan pengumpulan data sebaik mungkin. Pengumpulan data dibantu 6 orang enumerator mahasiswi semester akhir DIII kebidanan, meskipun telah dilakukan persamaan persepsi, bias tetap dapat terjadi misalnya saat memberikan kuisioner pertanyaan stigma dan diskriminasi tanpa terlebih dahulu memberikan arahan yang baik tentang bagaimana responden harus menjawab atau subjek penelitian menyembunyikan kondisi yang sebenarnya.

Hasil analisa statistik menunjukkan bahwa ibu hamil yang memiliki Stigma dan Diskriminasi yang rendah 0,401 kali lebih memanfaatkan pelayanan VCT dibandingkan dengan ibu hamil yang 
memiliki stigma dan diskriminasi yang tinggi dengan Confidence Interval (CI) 0,199-0,811. Untuk hasil nilai POR yang bersifat protektif (karena nilainya $<1$ ), bisa dibalik dengan menjadikan nilai tersebut 1/POR. Maka menjadi 1/0,401 dan bila dihitung 1 dibagi 0,401 menjadi 2,49. Dapat diinterpretasikan bahwa ibu hamil yang memiliki stigma dan diskriminasi yang tinggi 2,49 kali lebih besar untuk memanfaatkan pelayanan VCT dibandingkan ibu hamil yang memiliki stigma dan diskriminasi yang rendah.

Hal ini tidak sejalan dengan Penelitian (Pangaribuan, 2017) tentang Pengaruh Stigma dan Diskriminasi ODHA terhadap Pemanfaatan VCT di Distric Sorong Timur Kota Sorong didapatkan bahwa Stigma dan Diskriminasi yang sangat tinggi terhadap ODHA berpengaruh kuat dengan pemanfaatan layanan VCT, dengan kata lain bahwa karena takut stigma dan diskriminasi maka hampir tidak ada masyarakat secara sadar dan sukarela datang memeriksakan status HIVnya.

Stigma dan diskriminasi terhadap penderita HIV AIDS akan berdampak terhadap upaya pencegahan HIV seperti orang akan enggan untuk melakukan tes HIV karena takut akan mendapatkan stigma dan diskriminasi apabila hasil tesnya positif. Hal tersebut juga akan terjadi pada ibu hamil yang memiliki stigma akan cenderung untuk tidak mengikuti tes HIV. Namun dari ibu hamil yang memiliki stigma yang tinggi terhadap HIV/AIDS tidak semua memilih untuk tidak mengikuti tes HIV, ada beberapa ibu hamil yang tetap memilih untuk tes HIV dikarenakan sebagian besar responden sudah memiliki pendidikan tinggi dan orang yang berpendidikan tinggi akan lebih sadar untuk mencari informasi kesehatan tentang dirinya saat menghadapi kehamilan dan cenderung mengabaikan stigma dan diskriminasi yang mereka anggap memiliki efek yang signifikan dan berbahaya pada transmisi kesehatan dan penyakit yaitu menunda pencarian pengobatan dan kegagalan untuk mengungkapkan kondisi kesehatan yang sebenarnya. Terlepas dari ada stigma, ibu hamil yang memiliki pendidikan yang tinggi mungkin mengetahui prilaku beresiko yang dapat menyebabkan mereka bisa terinifeksi HIV sehingga mereka beranggapan perlu melakukan pemeriksaan HIV dan memanfaatkan pelayanan VCT. Selain itu responden mungkin percaya bahwa tenaga kesehatan atau konselor akan menjaga kerahasiaan hasil tes mereka sehingga stigma dan diskriminasi bukan menjadi penghambat untuk melakukan memanfaatkan VCT. Salah satu faktor yang dapat menjadi penghambat untuk pemanfaatan VCT diantaranya ketakutan dengan hasil yang positif. Hal ini sejalan dengan penelitian (Bock,2009) yang melaporkan bahwa salah satu faktor yang mempengaruhi pemanfaatan VCT adalah ketakutan mereka terhadap kemungkinan hasil tes positif.

\section{e. Pengetahuan}

Penelitian ini menunjukkan bahwa ada hubungan protektif antara variabel Pengetahuan dengan pemanfaatan pelayanan VCT. Hubungan protektif ini dapat terjadi karena bias informasi. walaupun pengumpulan data dilakukan dengan bantuan enumerator yang telah dilakukan persamaan persepsi terlebih dahulu jika saat memberikan kuisioner pertanyaan tanpa terlebih dahulu memberikan arahan yang baik tentang bagaimana responden harus menjawab dapat menyebabkan terjadinya bias.

Hasil analisa statistik menunjukkan bahwa ibu hamil yang memiliki pengetahuan yang baik 0,433 kali lebih memanfaatkan pelayanan VCT dibandingkan dengan ibu hamil yang memiliki 
pengetahuan yang kurang baik dengan Confidence Interval (CI) 0,209-0,898. Untuk hasil nilai POR yang bersifat protektif (karena nilainya $<1$ ), bisa dibalik dengan menjadikan nilai tersebut 1/POR. Maka menjadi 1/0,433 dan bila dihitung 1 dibagi 0,433 menjadi 2,3. Dapat diinterpretasikan bahwa ibu hamil yang memiliki pengetahuan yang kurang baik 2,3 kali lebih besar untuk memanfaatkan pelayanan VCT dibandingkan ibu hamil yang memiliki pengetahuan yang baik. Hal ini mungkin disebabkan bias seleksi, sehinga hubungan variabel pengetahuan tentang pelayanan VCT dengan pemanfaatan pelayanan VCT menunjukkan hubungan signifikansi terbalik. Hasil diatas tidak sesuai dengan Hasil penelitian (Nurhayati, 2016) yang menunjukkan ada hubungan yang signifikan antara pengetahuan dengan keikutsertaan ibu dalam pemeriksaan VCT dengan $P$ value 0,023 dan OR= 5 yang menunjukkan bahwa ibu yang memiliki pengetahuan tinggi 5 kali lebih memanfaatkan pemeriksaan VCT daripada ibu yang memiliki pengetahuan rendah.

Secara teoritis, pengetahuan tentang VCT merupakan variabel penting yang mempengaruhi seseorang untuk memanfaatkan fasilitas kesehatan. Semakin besar pengetahuan tentang VCT, semakin tinggi tingkat pemanfaatan fasilitas kesehatan yang dianggap mampu mengatasi masalah kesehatan tersebut. Klinik VCT/ bukan hanya digunakan oleh si penderita HIV/AIDS namun dapat juga dimanfaatkan oleh/orang yang sehat tapi beresiko terkena penyakit HIV/AIDS. Namun apa yang ditemukan dilapangan berbicara lain, justru para ibu hamil yang berpengetahuan baik tentang VCT dan belum memanfaat klinik VCT, kemungkinan hal dipengaruhi oleh mereka tidak tau harus pergi kemana untuk mendapatkan informasi dalam mencegahnya dan belum mengetahui benar manfaat dari klinik VCT.

Akses informasi dan sosialisasi tentang penyakit HIV/AIDS dan banyak tersedia dan mudah diakses oleh siapa saja, hal ini akan memberikan pengaruh yang baik terhadap pengetahuan tentang penyakit. Namun masih ada stigma di masyarakat yang memberikan penilaian yang buruk terhadap penderita HIV/AIDS yang akan menjadi penghambat dalam memanfaatkan klinik VCT. Selain itu tidak terlalu terdapat perbedaan pengetahuan antara orang yang memanfaatkan VCT dan orang yang tidak memanfaatkan VCT karena selain pengetahuan, pemanfaatan VCT juga dipengaruhi oleh faktor lainnya seperti sikap, kekhawatiran status dirinya HIV positif, kurang terjaminnya kerahasiaan klien, jauhnya jarak untuk mencapai Klinik VCT, serta lamanya waktu untuk kembali lagi ke Klinik VCT untuk melihat hasil tes, menjadi beberapa penyebab enggannya masyarakat datang ke Klinik VCT, sehingga pengetahuan yang baik tidak selalu meningkatkan pemanfaatan VCT.

\section{f. Pengetahuan}

Dari hasil penelitian yang dilakukan, variabel pendidikan tidak berhubungan signifikan dengan pemanfaatan pelayanan VCT yaitu dimana pvalue $0,384>0,05$. Hasil penelitian ini sejalan dengan penelitian yang dilakukan oleh (Juniwati, 2012) yang menyatakan bahwa tidak terdapat hubungan signifikan antara pendidikan dengan pemanfaatan klinik VCT.

Pendidikan merupakan suatu usaha mengembangkan kepribadian baik secara formal ataupun non formal, yang berlangsung seumur hidup. Pendidikan merupakan proses pengubahan sikap dan tata laku seseorang melalui upaya pengajaran dan pelatihan. Peningkatan pengetahuan tidak mutlak 
diperoleh di pendidikan formal, akan tetapi juga dapat diperoleh pada pendidikan non formal (Budiman, 2013)

Dari hasil penelitian di lapangan diperoleh ibu yang berpendidikan tinggi justru tidak memanfaatkan Pelayanan VCT, sehingga didapatkan hubungan yang tidak signifikan untuk variabel ini.

Kenyataan yang ada saat ini, hampir sebagian besar ibu yang memiliki pendidikan tinggi bekerja di luar rumah, sehingga akan menghambat waktunya untuk memanfaatkan Pelayanan VCT. selain itu, orang yang berpendidikan tinggi akan lebih sadar untuk mencari informasi kesehatan secara mandiri yang penting bagi dirinya saat menghadapi kehamilan dan cendrung akan lebih memilih pelayanan kesehatan yang lebih tinggi daripada Puskesmas. Teknologi yang berkembang pesat juga memudahkan seseorang untuk mengakses informasi kesehatan, sehingga pendidikan formal tidak lagi menjadi faktor utama yang terkait dengan perilaku kesehatan ibu. Selain itu kurikulum sekolah di Indonesia belum memfasilitasi pengetahuan tentang kesehatan reproduksi, sehingga pengetahuan tentang VCT tidak serta merta didapatkan di Sekolah.

\section{KESIMPULAN}

Proporsi ibu yang memanfaatkan pelayanan VCT yaitu 76 orang $(42,2 \%)$, sedangkan ibu yang tidak memanfaatkan pelayanan VCT sebanyak 104 orang (57,8\%). Variabel independen yang memiliki hubungan sebab akibat dengan pemanfaatan pelayanan VCT adalah dukungan suami/keluarga, dukungan tenaga kesehatan. Adapun hasil penelitian ibu yang tidak mendapatkan dukungan tenaga kesehatan berpengaruh 2 kali (POR:2,002; CI 95\%:0,994-4,033). Ibu yang tidak mendapatkan dukungan tenaga kesehatan berpengaruh 2,5 kali (POR:2,571; CI 95\%:1,274-5,187). Penelitian independen yang memiliki hubungan protektif terhadap variabel dependen adalah persepsi, stigma dan diskriminasi dan pengetahuan. Penelitian ini mempunyai 2 variabel yang confounding yaitu ketersediaan informasi dan umur. Variabel independen yang tidak memiliki hubungan statistik signifikan dengan Pemanfaatan VCT adalah pendidikan. Terdapat Variabel Interaksi yaitu antara Dukungan Tenaga Kesehatan dengan Pengetahuan

\section{SARAN}

Diharapkan kepada tenaga kesehatan untuk meningkatkan sosialisasi tentang program VCT, khususnya kepada ibu hamil yang berisiko dengan cara melakukan Komunikasi Informasi dan Edukasi baik ke individu maupun kelompok, melakukan sosialisasi melalui media massa, media elektronik, dan menyebarkan buku-buku, liflet, poster tentang VCT dan juga HIV/AIDS, meningkatkan screening dengan melakukan VCT untuk semua ibu hamil yang datang ANC ke fasilitas kesehatan.

\section{UCAPAN TERIMA KASIH}

Ucapan terima kasih ditujukan kepada Bapak Ahmad Hanafi, SKM, M.Kes selaku Ketua STIKes hang Tuah Pekanbaru, Ibu Dr. Mitra, SKM, MKM selaku Ketua Program Studi Magister Ilmu Kesehatan Masyarakat STIKes Hang Tuah Pekanbaru, Bapak Dr. dr. Toha Muhaimin, M.Sc selaku Pembimbing Utama dan Ibu Herlina Susmaneli, SKM, M.Kes selaku Pembimbing Pendamping yang telah banyak memberikan dukungan, arahan, bimbingan dan masukan dalam penulisan ini. 


\section{DAFTAR PUSTAKA}

Agnes, M., Kusmiyati, \& Iyam, M. (2010). Hubungan Pelaksanaan Standar Pelayanan Antenatal Dengan Keikutsertaan Ibu Hamil Untuk Konseling Dan Test HIV. Jurnal Ilmiah Bidan, Volume 2 No1.Hal 5561.

Aminudin, Adhaniar (2017). Hubungan Stigma terhadap ODHA dengan Minat Melakukan VCT pada ibu Rumah Tangga di Gedong Tengen Yogyakarta. Tesis. Fakultas Ilmu Kesehatan Universita Aisyiyah Yogyakarta

Arniti, Ni Ketut. (2014). Faktor-Faktor yang berhubungan dengan Penerimaan Tes HIV oleh Ibu hamil di Puskesmas Kota Denpasar, Tesis, Universita Udayana Denpasar

Ananda, J. N., Kamil, Ri., \& Rismayanti. (2012). Faktor Yang Berhubungan Dengan Pemanfaatan Voluntary Counselling and Testing ( vct) di RSP Jumpandang Baru Kota Makassar Tahun 2012, Jurnal Media kesehatan Masyarakat Indonesia 8(4).hal 225-232

Ardhiyanti, Y., Lusiana, N., \& Megasari, K. (2015). Bahan Ajar AIDS Pada Asuhan Kebidanan. Yogyakarta: Deepublish.

Bock, M. E. (2009). Factors Influencing The Uptake Of Hiv Voluntary Counselling And Testing In Namibia. Thesis.Vrije University Amsterdam.Netherlands, Hal. 12-29

Budiman, Riyanto, A. (2013). Kapita Selekta Kuesioner Pengetahuan dan Sikap dalam Penelitian Kesehatan. Jakarta. Salemba Medika

Burhan, R. (2015). Pemanfaatan Pelayanan Kesehatan Oleh Perempuan Terinfeksi \# Health Service Utilization in Women Living with HIV / AIDS. Jurnal Kesehatan Masyarakat (3), 33-38.

Churcher, Sian. (2013). Stigma Related to HIV and AIDS As a Barier To Accesing Health Care In Thailand : A Review Af Recent Literature. Available online at www. Searo.who.int/publications/journals/seajph ( Diakses 02 Agustus 2018)

Colon-Ramos U, Atienza AA, Weber D, Taylor M, Uy C, Y.A. (2009). Practicing what they preach : health behaviors of those who provide health advice to extensive social networks. J Health Commun, 14 (2).

Demissie, a.,Deribew, a., \& Abera, M. (2009). Determinants of Acceptance of Voluntary HIV Testing Among Antenatal Clinic Attendees at dil hora Hospital, Dire Dawa ,East Ethiopia.Ethiopia Jurnal Health Dev;23(2); 141-147

Deshpande, s., Basil, B. D., \& Basil, D. Z. (2009). Factors Influencing Healthy Eating Habits Among College Students: An Application Of The Health Belief Model, (MAY). Https://doi.org/10.1080/07359680802619834

Dirjen PP dan PL Kemenkes RI. (2010). Modul Pelatihan Konseling Dan Tes Sukarela (voluntary Counseliling And Testing ) / VCT untuk konselor profesional.Jakarta. Departemen Kesehatan RI

Dirjen PP dan PL Kemenkes RI. (2011). Survey Terpadu Biologis Dan Prilaku. Jakarta.Departemen Kesehatan RI

Fibriana, Arulita. Ika. (2013). Keikutsertaan Pelanggan Wanita Pekerja Seks Komersial Dalam Voluntary Counselling Test (vct).Jurnal Kesehatan Masyarakta 8(2), 161-165.

Fip-UPI, t. P. I. P. (2007). Ilmu Pendidikan Teoritis. Bandung: Imperial Bhakti Utama.

Glanz, K., Barbara, K., \& Viswanath. (2008). Health Behavior And Health Education. San Fransisco:JosseyBass.

Green, lw \& Kreuter, M. (N.D.). Health Promotion Planning: An Educational And Ecological Approach (4th ed).Myfield Publishing Company. Mountain View-Toronto- London

Indriyani, A. L. (2012). Gambaran Dan Faktor Yang Berhubungan Dengan Partisipasi VCT Pada Warga Binaan Pemasyarakatan di Rumah Tahanan Negara Kelas II A Pondok Bambu Tahun 2012.Tesis Program Pascasarjana Universitas Indonesia. Jakarta

Irianto, Koes. (2015). Kesehatan Reproduksi ( Reproductive Health )Teori \& Praktikum (1ST ED.). Bandung: Alfabeta.

Juniwati B, Darwita (2012). Hubungan Faktor Pendukung Dan Faktor Penguat Psk (Pekerja Seks Komersil)Denganpemanfaatanklinik Vct (Voluntary Conselling Testing) Diwilayah Kerja Puskesmas Wisata Bandar Baru Kecamatan Sibolangit Kabupaten Deli Serdang Tahun 2012.Tesis Program Pascasarjana Universitas Sumatera Utara. Medan

Kemenkes RI. (2006). Pedoman Pelayanan Konseling Dan Testing HIV/AIDS Secara Sukarela ( Voluntary Counselling And Testing ).Jakarta. Departemen Kesehatan

Kemenkes RI. (2017). Laporan Situasi Perkembangan HIV-AIDS \& PMS di Indonesia Januari - Maret 2017.http//www.aids.indonesia.or.id. Diakses tanggal 12 Juni 2018

Kementerian Kesehatan, RI. (2013). Rencana Aksi Nasional Pencegahan Penularan HIV Dari Ibu Ke Anak (PPIA) Indonesia 2013- 2017 Menuju Akses Universal.http// http://hivreview.net/book/rencanaaksi-nasional-pencegahan-penularan-hiv-dari-ibu-ke-anak-ppia-tahun-2013-2017/diakses 12 juni 
$\underline{2018}$

Kementeran Kesehatan, RI. (2012). Buku Pedoman Penghapusan Stigma dan Diskriminasi bagi Pengelola Program, Petugas Layanan Kesehatan dan Kader.Jakarta. Departemen Kesehatan RI

Kementerian Kesehatan, RI. (2014). Estimasi Dan Proyeksi HIV / AIDS di Indonesia Tahun 20112016.http//Siha.depkes.go.id/portal/file_upload/

Estimasi-dan_proyeksi_HIV_AIDS_di_Indonesia.pdf.diakses tanggal 28 Juni 2108

Lapau, B. (2013). Metode Penelitian Kesehatan. Jakarta. Yayasan Pustaka Obor Indonesia

Lapau, B. (2013). Prinsip dan Metode Epidemiologi. Jakarta. FKUI

Legiati, T. P., Shaluhiyah, Z., \& Suryoputro, A. (2010). Perilaku Ibu Hamil Untuk Tes HIV di Kelurahan Bandarharjo Dan Tanjung Mas Kota Semarang. Jurnal Promosi Kesehatan,153-164.

Mitra (2015). Manajemen dan Analisis Data Kesehatan. (A. A. C, Ed). Yogyakarta : CV. Andi Offset

Namazzi, Julie. Abimanyi. (2010). Determinants Of Using Voluntary Counselling And Testing for HIV / AIDS in Kenya. Monash University: Journal of Management Policy and Practice. http://www.nabussinespress.com/JMPP/NamazziWeb.pdf. diakses 25 Mei 2018

Notoatmodjo, S. (2007). Promosi Kesehatan Dan Ilmu Prilaku. Jakarta: Rineka Cipta.

Notoatmodjo, S. (2010). Ilmu Prilaku Kesehatan. Jakarta: Rineka Cipta.

Novita, Nesi \& Fransisca, Y. (2011). Promosi Kesehatan Dalam Pelayanan Kebidanan. Jakarta: Salemba Medika.

Nurhayati. (2016). Faktor - Faktor Yang Berhubungan Dengan Keikutsertaan Ibu Hamil Dalam Pemeriksaan VCT di Puskesmas.Jurnal Human Care.Volume 1(Nomor 3).

Pangaribuan, Sariana (2017). Pengaruh Stigma dan Diskriminasi ODHA terhadap Pemanfaatan VCT di Distrik Sorong Timur Kota Sorong. Junal Global Heatlh Science.Volume 2 (Nomor ).

Priyoto. (2014). Teori dan Prilaku dalam Kesehatan. Yogyakarta :Nuha Medika

Retnaningsih, Ekowati (2013). Akses Layanan Kesehatan. Jakarta : Raja Grafindo Persada

Riyanto, A. (2013). Kapita Selekta Kuesioner Pengetahuan Dan Sikap dalam Penelitian Kesehatan. Jakarta: Salemba Medika.

Siregar, D. (2015). HIV dan AIDS Untuk Mahasiswa Program Studi Ilmu Kesehatan masyarakat. Jakarta: Uni Pres.

Siregar, M.Sakti (2012). Mutu Pelayanan klinik VCT dengan Pemanfaatan Klinik VCT oleh Warga Binaan Risiko HIV/AIDS di Rumah Tahanan Negara Klas I Medan. Tesis Program Pascasarjana Universitas Sumatera Utara. Medan

Syahrir, W., \& Amiruddin, R. (2013). faktor Yang Berhubungan Dengan Pemanfaatan Klinik Voluntary Counseling And Testing ( VCT ) di Puskesmas Kota Makassar. Tesis Pasca Sarjana. Fakultas Kesehatan Masyarakat. Universitas Hasanuddin.Makasar

UNAIDS, (2017). UNAIDS Data.(diakses tanggal 25 Mei 2018)Available from http://www.unaids.org/en/resources/documents/2017/2017_data_book

Yulianti, Dina. (2011). Hegemoni Epistemic Community Dalam Program Harm Reduction UNAIDS ( Joint United Nations Programme On HIV / AIDS ): Studi Kasus di LSM Rumah Cemara. Tesis Program Pascasarjana Fakultas Ilmu Sosial Dan Ilmu Politik Universitas Padjadjaran .Bandung 